\title{
A New Method of Estimating Equilibrium Real Exchange Rate in Developing Countries
}

\author{
Renhong $\mathrm{Wu}^{1}$ \\ ${ }^{1}$ Independent Consultant, Richmond, Virginia, USA \\ Correspondence: Renhong Wu, 14118 Jeffries Terrance, Midlothian, Virginia, 23114. USA. Tel: 804-601-3296. \\ E-mail: rwu826@gmail.com
}

Received: January 18, 2016

Accepted: February 23, 2016

Online Published: February 25, 2016

doi:10.5539/ijef.v8n3p171

URL: http://dx.doi.org/10.5539/ijef.v8n3p171

\begin{abstract}
How to assess the misalignments of real exchange rate in developing countries has been a difficult and unresolved issue. Over the decades, researchers have not found desirable methods to estimate the "Equilibrium Exchange Rate". The Purchasing Power Parity (PPP) approach has limitations, and the fixed or managed floating exchange rate regimes in developing countries make the estimating more difficult. The purpose of this paper is to discuss the limitations of the Macroeconomic Balance approach and the existing PPP approach for estimating equilibrium exchange rate in developing countries, and introduce a new method-the Adjusted PPP method to assess exchange rate in developing countries. The new method includes the Human Development Index (HDI) to adjust the traditional PPP estimates. By introducing the adjustments of HDI, the big quality differences in non-tradable goods and services between developed and developing countries are adjusted for the exchange rate estimates. Also, as a case study, the paper estimated the exchange rate in China of 1991-2013.
\end{abstract}

Keywords: exchange rate, macroeconomic balance approach, PPP, adjusted PPP, HDI

\section{Introduction}

How to assess the misalignments of real exchange rate in developing countries has been a difficult and unresolved issue. Over the decades, researchers have not found desirable methods to estimate the "Equilibrium Exchange Rate". The Purchasing Power Parity (PPP) has limitations, and the fixed or managed floating exchange rate regimes in developing countries make the estimating more difficult. Due to the government interventions and the not well developed markets, the exchange rate can be heavily distorted and the distortion can last for a long period in developing countries.

The purpose of this paper is to discuss the limitations of Macroeconomic Balance approach and existing PPP approach for estimating equilibrium exchange rate in developing countries, and introduce an adjusted PPP method to estimate the equilibrium exchange rate. The paper is organized as follows: the first section is introduction. The second section is to discuss the limitations of Macroeconomic Balance approach. The third section is to discuss the limitations of existing PPP approach. The fourth section introduces an adjusted PPP method to assess exchange rate in developing countries, and estimate the exchange rate in the case of China in 1991 - 2013. The last section is conclusion remarks.

\section{The Limitations of Macroeconomic Balance Approach}

The macroeconomic balance approach focuses on the concept of fundamental equilibrium exchange rate (FEER). The theoretical concept of FEER was largely credited to the works of Williamson $(1983,1994)$. According to Williamson (1994), FEER is a real effective exchange rate that can achieve internal and external balance simultaneously for an economy or a number of given countries. The internal balance is reached when the economy is at full employment output with low inflation rate. The external balance can be indicated as a sustainable current account balance. The FEER will lead to a country's macroeconomic balance: the underline or "Norm" current account (CA) equals to the domestic saving (S) over domestic investment (I): CA = S - I. The main assumption of the macroeconomic balance approach is that the current account can be adjusted by real exchange rate: for example, an increase in the real exchange rate (real domestic currency appreciation) will lead to a decline of exports and an increase in imports, and so the current account position is decline.

In recent studies, Cline and Williamson $(2008,2010)$ refined the FEER definition: FEER is expected to be 
sustainable to generate a current account surplus or deficit that matches the country's underlying capital flow with internal balance. Also, Cline $(2008,2015)$ developed an operational model of symmetric matrix inversion method (SMIM) to estimate the FEER for more than 30 countries.

The macroeconomic balance approach is also refined and employed with econometric models for empirical studies by the International Monetary Fund (see IMF, 2006; Lee et al., 2008). Based on IMF, this approach is employed to exchange rate assessments with three steps: estimates the equilibrium relationship between current account balances and a set of fundamentals; projects the equilibrium current accounts; and computes the real exchange rate that would close the gap between the estimated equilibrium current accounts and the underlying current account balance.

The macroeconomic balance approach is well developed at concept or theoretical frame level, but it has challenges and difficulties at empirical analysis on exchange rate assessments. Many researchers have used different econometric models that are based on the macroeconomic balance approach to estimate the FEER or equilibrium real exchange rate, but the results have had inconsistence or wide discrepancies (see Isard, 2007; Isard \& Faruqee, 1998; Bussière, Zorzi, Chudik, \& Dieppe, 2010). By testing several empirical models, Cheung, Chinn and Pascual (2005) find that based on the different model specifications, different data time span and different currencies, the estimate results can be vary, and no model consistently outperforms a random walk by a mean squared error measure. Driver and Westaway (2004) note that the differences of empirical estimates of the equilibrium exchange rates can be explained by a range of theoretical models and by horizons: short-run, medium-run, and long-run. The IMF (2006) empirical results of the macroeconomic balance approach show that a country more open to trade will be able to close the current account gap with less exchange rate adjustment, and the estimates can be subject to the potential instability of the underlying macroeconomic links. Dunaway, Leigh, and $\mathrm{Li}$ (2006) use the macroeconomic balance approach and other approach to estimate China's equilibrium exchange rate and note that small changes in model specifications, explanatory variables definitions, and time periods can lead to substantial differences in estimate results.

Moreover, the FEER framework assumes there are no restrictions on trade and capital flow in the economy (Cline \& Williamson, 2010), so the macroeconomic balance approach has additional difficulties to estimate the exchange rate alignments in developing countries. In developing countries, the capital markets and goods markets are not well developed, governments can intervene the exports and imports heavily and there are capital flow controls. These factors have strong effects on the current account balances. For example, Cheung, Chinn and Fujii (2009) find that in China changes in the exchange rate do not show quantitatively large effects on the multilateral or bilateral trade flows, and the modeling estimate results for trade elasticity are sensitive to model specifications and time trends.

\section{The Limitations of Existing PPP Approach}

The PPP theory was introduced by Gustav Cassel $(1918,1922)$. The PPP theory is that if expressed in a common currency and the price level is equal in home and foreign country, the purchasing power of one currency unit should be the same in both economies. The fundamental condition of PPP theory is the law of one price, which states if by a common currency, the price of an internationally traded good should be the same in any country of the world.

The PPP is related to the real exchange rate (RER) notation: $\mathrm{RER}=\left(\mathrm{E}^{*} \mathrm{P}\right) / \mathrm{P}^{*}$, where $\mathrm{E}$ is nominal exchange rate, $\mathrm{P}$ is local country price level; $\mathrm{P}^{*}$ is foreign price level.

Many studies show, however, the PPP theory is not strongly supported by empirical data. There is enormous literature on the empirical studies. For example, Rogoff (1996) presents a very good survey on the studies. He states the consensus of empirical studies is that short-run deviations from PPP are large and volatile, and in long-run the speed of the convergence to PPP is extremely slow. Taylor A. and Taylor M. (2004) suggest the empirical results show the short-run PPP does not hold, but long-run PPP may hold in the sense that there is significant mean reversion of real exchange rate.

There are still arguments on the long-run PPP empirical evidence. For example, Froot and Rogoff (1994) test the long-run PPP by using 1630-1789 disaggregated price data in England and France with Wheat, Charcoal and Butter, and note the results are positive that show the long-run convergence to PPP and the most convincing evidence comes from fixed-rate period data. However, Isard (2007) find the PPP methodology alone would not save as a satisfactory framework for choosing a conversion rate. He uses the 1970-2000 England and Germany data and the estimate results show that the pound is overvalued from 10 percent to over 40 percent by using five different real exchange rate measurements: CPI, producer prices, export prices, GDP deflator, and unit labor costs. By using 100-year US and UK data series and doing econometric tests, Engel (2000) argues there may be 
a non-stationary component and large size biases in tests for long-run PPP.

A lot studies have tried to explain why the PPP theory lack of evidence of empirical research. For example, Krugman (1990) and Rogoff (1996) tried to explain the purchasing power parity puzzle with following reasons: there is imperfect competition or segmentation in international good markets; there are transportation costs, tariffs and nontariff barriers, information costs, and lack of labor mobility. Another important reason is the arguments of differential productivity between tradable and non-tradable goods (see Balassa, 1964; Samuelson, 1964). The higher productivity in tradable sector leads the salary increase of non-tradable sectors, and so leads higher price levels in non-tradable. Since many tradable goods have non-tradable as inputs or as facilities, such as office or factories, power supply, transportations, etc. so there will be price differences in the tradable goods among countries. It can be noted, in developing countries the productivity differential between tradable and non-tradable sector is much bigger then developed countries.

This paper likes to point out: there can be more reasons that the PPP theory is not strongly supported by empirical data. One of them is that there are big differences in the quality of non-tradable goods and services between developed and developing countries. This leads to excessive higher estimates of PPP or excessive higher PPP exchange rates for developing countries. For example, there are big differences in education quality between developed and developing countries. In 2000-2007, the education expenditure of GDP was 5.5\% in US, but it was $1.9 \%$ in China (UNDP, HDI 2010 Report, pp. 202-203). In 1998, the expenditure per primary student (by PPP) was $\$ 6,367$ in US, but it was $\$ 138$ in China (World Bank Data, 2013). Especially, the quality of elementary school education in developing countries is significantly poor than developed countries. In 2005-2008, the pupil teacher ratio was 18.3 in China, but it was 14.3 in US (UNDP, HDI 2010 Report. p. 201). In 2005, some elementary schools in rural areas of China still did not have computers for students to use. Moreover, the quality of healthcare has big differences between developing and developed countries. For example, in 2007, per capital expenditure on health (by PPP) was \$7,285 in US, but it was \$233 in China. In 2000-2009, the numbers of physician per 10,000 populations was 27 in US, and it was 14 in China (UNDP, HDI 2010 Report, pp. 197-198).

In practice, there are limitations of estimating the PPP exchange rates. Table 1 lists the PPP estimates of exchange rates from World Bank's World Development Indicators (WDI, May 2015 database). The PPP estimates made great contributions to international comparison and national income accounts, but they have limitations due to the difficulty with numbers construction methodologies and data collections. Deaton and Heston (2008) stated the PPP estimates still had technical imperfects in the construction of price indexes (such the selection of a common set of goods, etc.) and it was "extremely difficult" to compare some non-tradable goods and services among countries, such as government services, healthcare, education, etc.

Table 1. China's exchange rates: PPP estimates and adjusted PPP estimates

\begin{tabular}{cccc}
\hline Year & Nominal Exchange Rate & PPP Estimates & Adjusted PPP Estimates \\
\hline 1991 & 5.323 & 1.767 & 2.538 \\
1992 & 5.515 & 1.869 & 2.951 \\
1993 & 5.762 & 2.102 & 3.245 \\
1994 & 8.619 & 2.483 & 3.737 \\
1995 & 8.351 & 2.766 & 4.013 \\
1996 & 8.314 & 2.891 & 3.924 \\
1997 & 8.290 & 2.885 & 3.815 \\
1998 & 8.279 & 2.829 & 3.722 \\
1999 & 8.278 & 2.753 & 3.582 \\
2000 & 8.279 & 2.747 & 3.552 \\
2001 & 8.277 & 2.741 & 3.562 \\
2002 & 8.277 & 2.715 & 3.423 \\
2003 & 8.277 & 2.731 & 3.415 \\
2004 & 8.277 & 2.842 & 3.509 \\
2005 & 8.194 & 2.862 & 3.980 \\
2006 & 7.973 & 2.882 & 3.948 \\
2007 & 7.608 & 3.022 & 4.066 \\
2008 & 6.949 & 3.195 & 4.239 \\
2009 & 6.831 & 3.150 & 4.114 \\
\hline & & &
\end{tabular}




\begin{tabular}{cccr}
\hline Year & Nominal Exchange Rate & PPP Estimates & Adjusted PPP Estimates \\
\hline 2010 & 6.770 & 3.319 & 4.299 \\
2011 & 6.461 & 3.506 & 4.498 \\
2012 & 6.312 & 3.512 & 4.480 \\
2013 & 6.195 & 3.520 & 4.474 \\
\hline
\end{tabular}

Notes. Nominal Exchange Rate, PPP Estimates and Adjusted PPP Estimates are 1US\$:RMB (Chinese currency).

PPP Estimates: Data are from World Bank WDI database, May 2015.

Adjusted PPP Estimates: PPP Estimates Adjusted by HDI. HDI are from UNDP of 2014 HDR and 1994-2010 HDR.

\section{An Adjusted PPP Method and the Estimates for the Case of China}

In order to overcome the limitations of PPP approach, this paper introduces an adjusted PPP method to assess the misalignments of real exchange rate in developing countries. The new method includes the Human Development Index (HDI) to adjust the traditional PPP estimates:

$$
\text { Adjusted PPP Rate }=\text { PPP * (US HDI/Local Country HDI })
$$

The HDI is developed by United Nations Development Programme (UNDP). HDI has been reported on the annual "Human Development Report" of UNDP since 1990. The HDI is a more comprehensive measure of human and country development: it measures a long and healthy life, access to knowledge, and gross national income (GNI) per capital. According to UNDP (2010, pp. 215-217), the HDI is the geometric mean of normalized indices measuring achievements in three basic dimensions: life expectancy index, education index, and GNI index. The life expectancy index is measured by life expectancy at birth. The increase in human longevity can reflect improvements in public health and in access to primary healthcare service. The education index is measured by mean years of schooling and expected years of schooling.

As the definition of HDI indicated, HDI includes more measurements of non-tradable goods and services, and takes into the account of the quality of non-tradable goods and services, such as the quality of education, quality of healthcare, housing, etc.

Based on World Bank and UNDP data and by using the adjusted PPP method, Table 1 lists three reported and estimated exchange rates for China during 1991-2013:

Nominal Exchange Rate = official reported exchange rate;

PPP estimate $=$ World Bank estimates;

Adjusted PPP Method rate $=$ PPP * (US HDI/China HDI).

Table 1 show, the Adjusted PPP Method estimates indicate that the nominal exchange rate in China were under valued in 1991-2013. For example, in 2001 the nominal exchange rate is 1US\$: 8.277 RMB; PPP estimate is 2.741 RMB; the Adjusted PPP method is 3.562 RMB. In 2005, the nominal exchange rate is 1US\$:8.194 RMB; PPP estimate is 2.862; Adjusted PPP method is 3.980. In 2010, the nominal exchange rate is 1US\$: 6.770 RMB; PPP estimate is 3.319; Adjusted PPP method is 4.299. In 2013, the nominal exchange rate is 1US\$: 6.195 RMB; PPP estimate is 3.520; Adjusted PPP method is 4.474.

In order to estimate the effect and significance of HDI for the real exchange rate, the following estimate equation is created:

$$
\log R E R=\log G D P G R R T I+\log H D I R T I+N F A \_G D P
$$

Where RER is real exchange rate. $\mathrm{RER}=\left(\mathrm{E}^{*} \mathrm{P}\right) / \mathrm{P} *$;

where $\mathrm{E}=$ nominal exchange rate;

$\mathrm{P}=$ China CPI; $\mathrm{P}^{*}=$ US CPI.

GDPGRRTI $=$ ratio of GDP growth rate (China to US).

HDIRTI $=$ ratio of HDI (China to US).

NFA_GDP = China net foreign assets /GDP (in billion US\$).

The assumptions of the estimate equation are that the real equilibrium exchange rate is mainly determined by productivity (the Balassa-Samuelson effects (see Balassa, 1964; Samuelson, 1964) peroxided by GDP growth rate), human and country development level (peroxided by HDI), and net foreign assets.

The data used are 1985-2013 (data from World Bank and UNDP. The valid observations are 26. Due to the log 
transformation, 3 observations with negative RER are excluded.), and the estimate equation and estimated results are following:

The estimate equation with lag $\mathrm{t}-1$ is

$$
\log R E R t=\beta 0+\beta 1 \log G D P G R R T I t-1+\beta 2 \operatorname{LogHDIRTIt}-1+\beta 3 N F A \_G D P t-1+\varepsilon t
$$

The estimate results are:

$$
\begin{aligned}
& \text { LogRER }=-2.3965+1.0937 \operatorname{LogGDPGRRTI}-7.8572 \operatorname{LogHDIRTI}+23.8068 \text { NFA_GDP } \\
& (-3.59) \quad(4.73) \\
& (0.0017) \quad(0.0001) \quad(<.0001)
\end{aligned}
$$

Adjusted R-square $=0.6903$.

(In above estimates, the first line values in parentheses are $\mathrm{t}-\mathrm{value}$, and the second line values in parentheses are p-values.)

The estimate results show, the HDI ratio is statistically significant (with p-value $=<.0001$ ) in the estimate equation. That is, the HDI ratio has important effects on real exchange rate. Also, as expected, the GDP growth ratio and NFA are statistically significant.

\section{Conclusion}

This paper has discussed the limitations of Macroeconomic Balance approach. The over decades empirical studies show, based on the different model specifications, different baseline time points and data time span, the estimate results by the approach can be vary. The paper has also discussed the limitations of existing PPP approach. The PPP exchange rate is inclined to over estimate the exchange rates in developing countries (over valued), because the estimates have not taken into the account of the quality differences in non-tradable goods and services between developed and developing countries, and many studies show that the PPP theory is not strongly supported by empirical data.

This paper has introduced a new method-the Adjusted PPP method to assess exchange rate in developing countries. The Adjusted PPP Method rate $=$ PPP $*($ US HDI/Local Country HDI). The new method includes the Human Development Index (HDI) to adjust the traditional PPP estimates. By introducing the adjustments of HDI, the big quality differences in non-tradable goods and services between developed and developing countries are adjusted for the exchange rate estimates.

Also, as a case study, the paper estimated the exchange rate in China using the data of 1985-2013. The estimate results in the regression model show, the HDI ratio is statistically significant. That is, the HDI ratio has important effects on real exchange rate. The Adjusted PPP Method estimates indicate that the nominal exchange rate in China were under valued in 1991-2013.

\section{Acknowledgements}

I am grateful to the anonymous reviewers for helpful comments and suggestions. The author is solely responsible for any errors and misinterpretations.

\section{References}

Balassa, B. (1964). The purchasing power parity doctrine: a reappraisal. Journal of Political Economy, 72(6), 584-596. http://dx.doi.org/10.1086/258965

Bussière, M., Ca' Zorzi, M., Chudik, A., \& Dieppe, A. (2010). Methodological advances in the assessment of equilibrium exchange rates. ECB Working Paper, No. 1151. European Central Bank.

Cassel, G. (1918). Abnormal deviations in international exchanges. Economic Journal, 413-415. http://dx.doi.org/10.2307/2223329

Cassel, G. (1922). Money and Foreign Exchange After 1914. New York: Macmillan.

Cheung, Y., Chinn, M., \& Fujii, E. (2009). China's current account and exchange rate. NBER Working Paper, No. 14673. National Bureau of Economic Research. http://dx.doi.org/10.2139/ssrn.1412620

Cheung, Y., Chinn, M., \& Pascual, A. (2005). Empirical exchange rate models of the nineties: Are any fit to survive?, Journal of International Money and Finance, 24(7), 1150-1175. http://dx.doi.org/10.1016/j.jimonfin.2005.08.002

Clark, P., \& McDonald, R. (1998). Exchange rates and economic fundamentals: A methodological comparison of BEERs and FEERs. IMF Working Paper, 98/67. International Monetary Fund. 
Cline, W. R. (2008). Estimating consistent fundamental equilibrium exchange rates. Working Paper 08-6 (July). Washington DC, Peterson Institute for International Economics.

Cline, W. R. (2015). Estimates of fundamental equilibrium exchange rates. Washington DC, Peterson Institute for International Economics, No. PB15-20.

Cline, W. R., \& Williamson, J. (2010). Estimates of fundamental equilibrium exchange rates. Washington DC, Peterson Institute for International Economics, No. PB10-15.

Deaton, A., \& Heston, A. (2008). Understanding PPPs and PPP-based national accounts. NBER Working Paper, No. 14499. National Bureau of Economic Research.

Dornbusch, R. (1988). Real exchange rates and macroeconomics: A selective survey. NBER Working Paper, No. 2775. National Bureau of Economic Research.

Driver, R., \& Westaway, P. (2004). Concepts of equilibrium exchange rate. Bank of England Working Papers, No. 248. Elsevier Science, pp. 1689-1729. http://dx.doi.org/10.2139/ssrn.723981

Dunaway, S., Leigh, L., \& Li, X. (2006). How robust are estimates of equilibrium real exchange rates: The case of China. IMF Working Paper, WP/06/220. International Monetary Fund.

Engel, C. (2000). Long-run PPP may not hold after all. Journal of International Economics, 57, 243-273. http://dx.doi.org/10.1016/S0022-1996(99)00011-2

Frankel, J. A., \& Rose, A. K. (1995). Empirical research on nominal exchange rates. In G. Grossman, \& K. Rogoff (Eds.), Handbook of International Economics (Vol. III).

Froot, K., \& Rogoff, K. (1994). Perspectives on PPP and long-run real exchange rates. NBER Working Papers, No. 4952. National Bureau of Economic Research.

IMF. (2006). Methodology for CGER exchange rate assessments. Research Department, International Monetary Fund.

Isard, P. (2007). Equilibrium exchange rates: Assessment methodologies. IMF Working Paper, No. 296. International Monetary Fund. http://dx.doi.org/10.5089/9781451868593.001

Isard, P., \& Faruqee, H. (1998). Exchange rate assessment: Extensions of the macroeconomic balance approach. IMF Occasional Paper, No. 167. International Monetary Fund. http://dx.doi.org/10.5089/9781557757319.084

Krugman, P. (1990). Equilibrium exchange rates. In W. H. Branson, J. A. Frenkel, \& M. Goldstein (Eds.), International Policy Coordination and Exchange Rate Fluctuations (pp. 159-196). University of Chicago Press.

Lee, J. et al. (2008). Exchange rate assessments: CGER methodologies. IMF Occasional Paper, No. 261. International Monetary Fund. http://dx.doi.org/10.5089/9781589066380.084

MacDonald, R. (2000). Concepts to calculate equilibrium exchange rates: An overview. Discussion Paper 3/00, Economic Research Group of the Deutsche Bundesbank.

MacDonald, R., \& Ricci, L. (2001). PPP and the Balassa Samuelson effect: The role of the distribution sector. IMF Working Paper, WP/01/38. International Monetary Fund. http://dx.doi.org/10.5089/9781451845693.001

Meese, R., \& Rogoff, K. (1983). Empirical exchange rate models of the seventies: Do they fit out of sample? Journal of International Economics, 14, 3-24. http://dx.doi.org/10.1016/0022-1996(83)90017-X

Ricci, L., Ferretti, M., \& Lee, J. (2008). Real exchange rates and fundamentals: A cross-country perspective. IMF Working Paper, WP/08/13. International Monetary Fund. http://dx.doi.org/10.5089/9781451868753.001

Rogoff, K. (1996). The purchasing power parity puzzle. Journal of Economic Literature, 34, 647-668.

Samuelson, P. A. (1964). Theoretical notes on trade problems. Review of Economics and Statistics, 46, 145-154. http://dx.doi.org/10.2307/1928178

Taylor, A. M., \& Taylor, M. P. (2004). The purchasing power parity debate. NBER Working Papers, No. 10607, National Bureau of Economic Research. http://dx.doi.org/10.1257/0895330042632744

UNDP. (1994, 2001, 2007, 2010, 2014). Human Development Report. United Nations Development Programme, New York. 
Willett, T. D., \& Wihlborg, C. (1990). International capital flows, the Dollar, and U.S. financial policies. In Haraf, W. S., \& Willett, T. D. (Eds.), Monetary Policy for A Volatile Global Economy (pp. 51-88). Washington DC: American Enterprise Institute Press.

Williamson, J. (1983). The exchange rate system. Policy Analyses in International Economics. Institute of International Economics, Washinton DC.

Williamson, J. (1994). Estimates of FEERs. In J. Williamson (Ed.), Estimating Equilibrium Exchange Rates. Institute for International Economics, Washington DC.

\section{Copyrights}

Copyright for this article is retained by the author(s), with first publication rights granted to the journal.

This is an open-access article distributed under the terms and conditions of the Creative Commons Attribution license (http://creativecommons.org/licenses/by/3.0/). 